
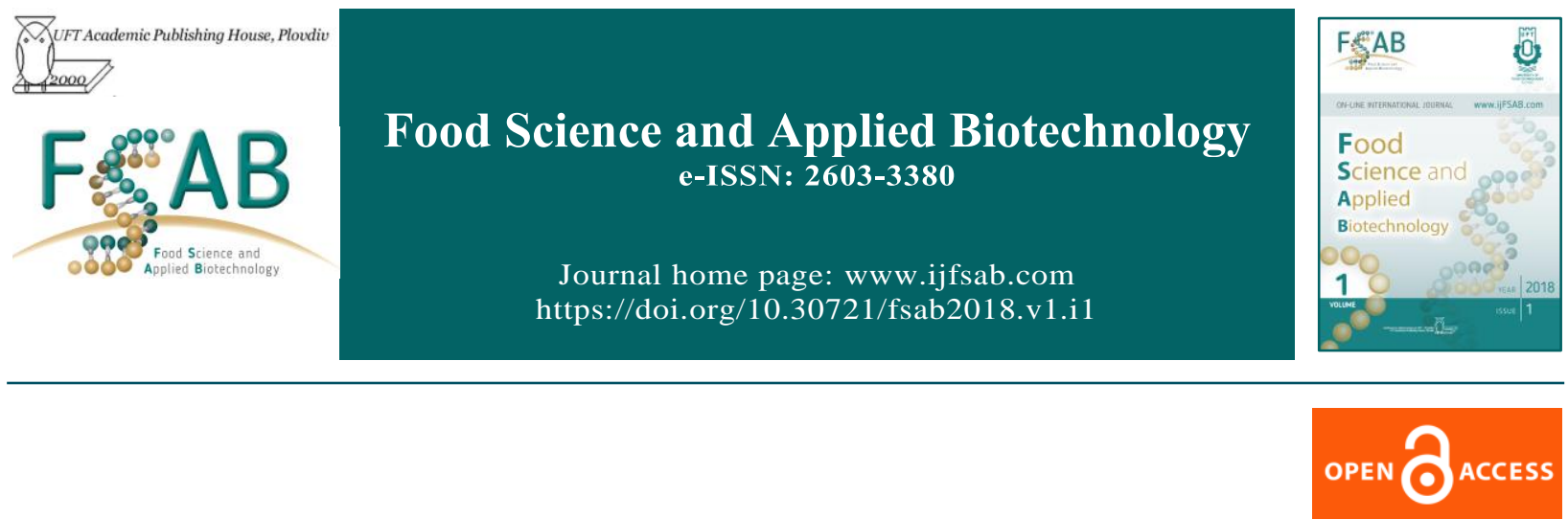

Research Article

\title{
Valorization of lavender waste - obtaining and characteristics of polyphenol rich extracts
}

Anton M. Slavov ${ }^{1}$, Kostadinka B. Karneva ${ }^{1}$, Ivelina N. Vasileva ${ }^{1}$, Petko N. Denev ${ }^{2}$, Rositsa S. Denkova ${ }^{3}$, Vasil T. Shikov ${ }^{4}$, Mariana N. Manolova ${ }^{5}$, Yana L. Lazarova ${ }^{1}$, Viara N. Ivanova ${ }^{6}$

${ }^{1}$ Department of Organic Chemistry and Inorganic Chemistry, Technological Faculty, University of Food Technologies, Plovdiv, Bulgaria

${ }^{2}$ Laboratory of Biologically Active Substances, Institute of Organic Chemistry with Centre of Phytochemistry, Bulgarian Academy of Science, Plovdiv, Bulgaria

${ }^{3}$ Department of Biochemistry and Molecular Biology, Technological Faculty, University of Food Technologies, Plovdiv, Bulgaria

${ }^{4}$ Department of Canning Technology, Technological Faculty, University of Food Technologies, Plovdiv, Bulgaria

${ }^{5}$ Department of Biochemistry and Microbiology, Biological Faculty, University of Plovdiv "Paisii Hilendarski, Bulgaria

${ }^{6}$ Department of Microbiology, Technological Faculty, University of Food Technologies, Plovdiv, Bulgaria

\begin{abstract}
Bulgaria became the leading producer of lavender oil in the last years. Due to the lower quantity of essential oil large amounts of waste were generated which distilleries usually discard, although the residues are rich source of biologically active substances. The objective of this study was to obtain polyphenol-rich extracts from lavender waste and to investigate their chemical composition and antioxidant capacity. Two wastes (Mirkovo, Bulgaria, 2016) were investigated - steam distilled (SD-L) and $\mathrm{CO}_{2}$-extracted lavender (CO2-L). The major aroma constituents found were linalool and linalyl acetate $-30.68 \%$ and $25.82 \%$, respectively, and the highest concentrations were found in the SD-L. The total flavonoids in CO2-L and SD-L were $2.91 \pm 0.11$ and $3.72 \pm 0.20 \mathrm{mg} \cdot \mathrm{g}^{-1}$ dry matter residue, respectively. The higher amount of phenolic acids was observed in the SD-L waste $2.62 \pm 0.19 \mathrm{mg} . \mathrm{g}^{-1}$, compared to $1.39 \pm 0.14 \mathrm{mg} \cdot \mathrm{g}^{-1}$ dry matter residue for $\mathrm{CO}_{2}$ extracted lavender. The antioxidant activity of the extracts was investigated by DPPH (SD-L $-355.48 \pm 23.12 \mu$ mol TE.g ${ }^{-1}$ DW waste; CO2-L $-283.21 \pm 17.04 \mu m^{2}$ TE. ${ }^{-1}$ DW waste) and FRAP (SD-L - 427.36 $\pm 26.54 \mu$ mol TE. ${ }^{-1}$ DW waste; CO2-L - 311.29 $\pm 18.17 \mu$ mol TE. $\mathrm{g}^{-1}$ DW waste). Both methods suggested that SD-L residue had higher antioxidant capacity and polyphenol content.

The lavender wastes (SD-L and CO2-L) showed strong antioxidant capacity with potential beneficial effect on addition in foodstuffs. For the first time lavender residues from $\mathrm{CO}_{2}$-extraction was investigated for its antioxidant activity, polyphenol composition and aroma metabolites, and comparison with SD-L was performed. In general, the results suggested that the lavender waste were promising source of antioxidants.
\end{abstract}

Keywords: lavender, waste valorization, polyphenols, antioxidant activity, $\mathrm{CO}_{2}$ extraction

\section{Abbreviations:}

ANOVA - analysis of variance; HORAC - Hydroxyl Radical Averting Capacity; BSTFA - N, O-Bis-(trimethylsilyl)trifluoroacetamide; DPPH - 2, 2-diphenyl-1-picrylhydrazyl; FRAP - ferric reducing ability of plasma; HPLC - high performance liquid chromatography; NIST - National Institute of Standards and Technology; ORAC $\quad-\quad$ oxygen radical absorbance capacity; RI - relative index (Kovats retention index)

$\square^{\square}$ Corresponding author: Ass.Prof. Anton Minchev Slavov, PhD; Department of Organic Chemistry and Inorganic Chemistry, Technological Faculty, University of Food Technologies, 26 Maritza Blvd. BG-4002 Plovdiv, Bulgaria, tel.: +359 32603 681; mobile: +359885 251 284 ; fax: +35932644005; E-mail: antons@uni-plovdiv.net

\section{Article history:}

Received 1 December 2017

Reviewed 27 December 2017

Accepted 12 January 2018

Available on-line 14 March 2018

https://doi.org/10.30721/fsab2018.v1.i1.5 (C) 2018 The Authors. UFT Academic publishing house, Plovdiv 


\section{Introduction}

The lavender is among the most processed crops by the essential oil manufacturers. The main industrially exploited species are the true lavender (Lavandula angustifolia Mill.), lavandin (Lavandula $x$ intermedia Emeric ex Loiseleur) and spike lavender (Lavandula spica D.C.). Bulgaria, France, UK, China, Ukraine, Spain, and Morocco are the biggest worldwide producers of essential lavender oil. In the last years Bulgaria overtaken on lavender plantations and lavender oil yield (around 100 tons produced yearly) the long-standing leader in this field France (Lesage-Meessen et al. 2015). The main specie grown in Bulgaria is the true lavender (Lavandula angustifolia Mill.). Due to the fact that the concentration of essential oil in the plant materials $(0.8-1.3 \%$ / fresh plant) is relatively low after extraction or distillation of the important biologically active substances large quantities of wastes remain. Throwing simply away or using as compost is among the very often used procedures to eliminate these wastes. But they could also serve as initial materials for recovery of valuable by-products which could be used in the food, cosmetic and perfumery industry. Alternative methods of valorization have also been applied in recent years - fermentation of distilled lavender and biotransformation of terpene compounds into valuable and difficult to chemically synthesize substances (Daramwar et al. 2012; ElgueaCulebras et al. 2016; Marumoto and Miyazawa 2011; Lesage-Meessen et al. 2015; Noma and Asakawa 2010), isolation of substances with strong antioxidant activity - apigenin, rosmarinic acid, luteolin, etc. (Lesage-Meessen et al. 2015; Méndez-Tovar et al. 2015), as well as the use of ethanol extracts from lavandin waste materials for potential antifungal activity (against Penicillium verrucosum Dierckx), a common microorganism causing loss in cheese production) (Lesage-Meessen et al. 2015).

Despite of this, very few studies are currently available on the chemical composition and antioxidant capacity of extracts of true lavender (Lavandula angustifolia Mill.) waste. Additionally, in the literature are missing data on the chemical composition and antioxidant capacity of wastes after supercritical $\mathrm{CO}_{2}$ extraction of lavender (Lavandula angustifolia Mill.). These observations determined the aim of the present work - to explore the possibility of utilization of spent lavender biomass (obtained by traditional steam distillation and supercritical $\mathrm{CO}_{2}$ extraction), with an emphasis on obtaining polyphenol rich extracts and to investigate their chemical composition and antioxidant capacity.

\section{Materials and Methods}

The lavender wastes were provided by ECOMAAT distillery (Mirkovo, Bulgaria, 2016). The first one was residue after steam distillation of the fresh bio lavender (SD-L) and the second one - residues of supercritical $\mathrm{CO}_{2}$ extracted bio lavender (CO2-L).

After treatment the SD-L waste was cooled down, inspected for elimination of impurities and dried under vacuum at $50^{\circ} \mathrm{C}$. The $\mathrm{CO} 2-\mathrm{L}$ waste was removed from the extraction cylinder and checked for impurities. Both wastes were stored at $-18^{\circ} \mathrm{C}$ until further treatment. All the solvents used were of analytical grade and purchased from local distributors. The $70 \%$ ethanolic extracts from two wastes of Lavandula angustifolia (steam distilled: SD-L, and extracted by supercritical $\mathrm{CO}_{2}$ : $\mathrm{CO} 2-\mathrm{L}$ were obtained according to Kratchanova et al. (2008).The total polyphenol content of ethanolic extracts was determined using the method described by Singleton and Rossi (1965). The antioxidant activity by ORAC and HORAC assays was measured as described by Č́iž et al. (2010). The DPPH and FRAP analysis were performed according to the procedure described in Slavov et al. (2017).

The individual phenolic and flavonoid components were analyzed on Agilent 1220 HPLC system (Agilent Technology, USA), equipped with binary pump and UV-Vis detector. Wavelength of $\lambda=280 \mathrm{~nm}$ was used. Separation was performed using Agilent TCC18 column $(5 \mu \mathrm{m}, 4.6 \mathrm{~mm} \times 250 \mathrm{~mm})$ at $25^{\circ} \mathrm{C}$. Mobile phases constituted of $0.5 \%$ acetic acid (A) and $100 \%$ acetonitrile (B) at flow rate 0.8 $\mathrm{ml} / \mathrm{min}$. The gradient conditions started with 
$14 \% \mathrm{~B}$, between $6 \mathrm{~min}$ and 30 linearly increased to $25 \% \mathrm{~B}$, then to $50 \% \mathrm{~B}$ at $40 \mathrm{~min}$. The standard compounds (gallic acid, 3,4-dihydroxy benzoic acid, chlorogenic acid, caffeic acid, pcoumaric acid, ferulic acid, ellagic acid, catechin, epicatechin, rutin, naringin, myricetin, quercetin, naringenin and kaempherol) were purchased from Sigma-Aldrich (Steinheim, Germany).The individual volatile and nonvolatile compounds in the ethanolic extracts were determined according to the following procedures:

1). Non-volatile substances $-0.2 \mathrm{ml}$ ethanolic extract was lyophilized and $50 \mu \mathrm{L}$ pyridine and $50 \mu \mathrm{LN}, \mathrm{O}$-Bis-(trimethylsilyl)-trifluoroacetamide (BSTFA) were added. The sample was incubated at $70^{\circ} \mathrm{C}$ for $40 \mathrm{~min}$. For analysis 1.0 $\mu \mathrm{L}$ from the solution was injected on gas chromatograph Agilent GC 7890 with masselective detector Agilent MD 5975 and column HP-5ms (30 m with diameter $0.32 \mathrm{~mm}$ and 0.25 $\mu \mathrm{m}$ thicknesses). The following temperature regimen was used - initial temperature $100^{\circ} \mathrm{C}$ (hold for $2 \mathrm{~min}$ ) then increase to $180^{\circ} \mathrm{C}$ with $15^{\circ} \mathrm{C} \cdot \mathrm{min}^{-1}$ (hold for $1 \mathrm{~min}$ ) and increase of the temperature to $300^{\circ} \mathrm{C}$ with $5^{\circ} \mathrm{C} \cdot \mathrm{min}^{-1}$ (hold for $10 \mathrm{~min}$ ); injector and detector temperatures $250^{\circ} \mathrm{C}$, helium was used as carrier gas at 1.0 $\mathrm{ml} . \mathrm{min}^{-1}$. The scanning range of mass-selective detector was $\mathrm{m} / \mathrm{z}=50-550$ in split-split mode (10:1).

2). Volatile substances $-1.0 \mathrm{ml}$ ethanolic extract was extracted with $1.0 \mathrm{ml}$ dichloromethane (triple). The combined organic layers were dried under vacuum at $30^{\circ} \mathrm{C}$. To the dry residue 100 $\mu \mathrm{L}$ dichloromethane was added. For analysis 1.0 $\mu \mathrm{L}$ from the solution was injected on gas chromatograph Agilent GC 7890 with masselective detector Agilent MD 5975 and column HP-5ms. The following temperature regimen was used - initial temperature was $40^{\circ} \mathrm{C}$ and then increase to $300^{\circ} \mathrm{C}$ with $5^{\circ} \mathrm{C} \cdot \mathrm{min}^{-1}$ (hold for $10 \mathrm{~min}$ ); injector and detector temperatures $250^{\circ} \mathrm{C}$, helium was used as carrier gas at 1.0 $\mathrm{ml} . \mathrm{min}^{-1}$. The scanning range of mass-selective detector was $\mathrm{m} \cdot \mathrm{z}^{-1}=40-400$ in splitless mode. The individual compounds were identified comparing the retention times and the relative index (RI) with those of standard substances and mas-spectral data from libraries of The Golm Metabolome Database and NIST'08 (National Institute of Standards and Technology, USA).

Statistical analysis. The analyses were run three times, and the data were given as mean values. Statistical significance was detected by analysis of variance (ANOVA, Tukey's test; value of $\mathrm{p}<0.05$ indicated statistical difference). The homogeneity of variances assumption was checked by Levene's test.

\section{Results and Discussions}

Obtaining of ethanolic extracts from lavender waste. Pretreatment of the plant materials with aqueous-ethanolic solutions is usually applied before extraction of polysaccharides from the raw or waste mass. The aim is to remove some low-molecular substances and secondary metabolites (pigments, sugars, etc.) which will hamper further extraction process. In our case it also aimed at obtaining of extracts rich on polyphenolic substances (Slavov et al., 2016). In previous experiments we have investigated the influence of the ethanol concentration on extractability of polyphenols and subsequent polysaccharide extractions (Slavov et al., 2017). Our findings showed that extraction with $70 \%$ ethanol solutions gave the optimum results for possibilities of combined valorization of the waste materials of Rosa damascena and for this reason we have decided the treatment of the lavender residues after $\mathrm{CO}_{2}$ extraction or steam distillation to be performed with $70 \%$ ethanol.

Total phenolic substances, individual phenolics and flavonoids, and antioxidant activity of ethanolic extracts from lavender waste. The obtained $70 \%$ ethanolic extracts were subjected to preliminary analysis for their total phenolic substances. The results from the analysis are shown in Table 1. 
Table 1. Polyphenols and antioxidant activity of $70 \%$ ethanol extracts of lavender wastes

\begin{tabular}{|c|c|c|c|c|c|c|}
\hline № & $\begin{array}{c}\text { Waste } \\
\text { material }\end{array}$ & $\begin{array}{c}\text { Total } \\
\text { phenolics, } \\
\text { mg.g }{ }^{-1} \mathrm{DW} \\
\text { waste }\end{array}$ & $\begin{array}{c}\text { DPPH, } \\
\mu \mathrm{mol} \text { TE. } \\
\mathrm{g}^{-1} \mathrm{DW} \\
\text { waste }\end{array}$ & $\begin{array}{c}\text { FRAP, } \\
\mu \text { mol TE. } \\
\text { g-1 DW }^{-1} \text { waste }\end{array}$ & $\begin{array}{c}\text { ORAC, } \\
\mu \text { mol TE. } \\
\mathrm{g}^{-1} \mathrm{DW} \\
\text { waste }\end{array}$ & $\begin{array}{c}\text { HORAC, } \\
\text { Hmol }^{-} \\
\text {GAE.g }^{-1} \\
\text { DW waste }\end{array}$ \\
\hline 1 & SD-L & $\begin{array}{c}10.75 \pm \\
0.91^{a}\end{array}$ & $\begin{array}{c}355.48 \pm \\
13.12^{a}\end{array}$ & & $\begin{array}{c}5368.09 \pm \\
92.61^{a}\end{array}$ & $\begin{array}{c}2862.85 \pm \\
71.22^{a}\end{array}$ \\
\hline 2 & CO2-L & $\begin{array}{l}7.52 \pm \\
0.62^{b}\end{array}$ & $\begin{array}{c}283.21 \pm \\
17.04^{b}\end{array}$ & $\begin{array}{c}311.29 \pm \\
18.17^{b}\end{array}$ & $\begin{array}{c}3133.74 \pm \\
101.64^{b}\end{array}$ & $\begin{array}{c}1967.62 \pm \\
69.37^{b}\end{array}$ \\
\hline
\end{tabular}

Data were expressed as Mean \pm SD $(n=3)$.

$\mathrm{a}, \mathrm{b}$ - different letters indicated that values of the means in the columns are significantly different $\left(p^{*}<0.05\right)$.

The content of total phenolic compounds in SD$\mathrm{L}$ residue were $25 \%$ more than in $\mathrm{CO} 2-\mathrm{L}$ which suggests that the $\mathrm{CO}_{2}$-extraction extracts better the biologically active substances present in the plant matrix. Since polyphenolic compounds present in the extracts are related to their antioxidative properties, in the subsequent experiments, the antioxidant activity of the ethanolic extracts was investigated employing several methods. It is well known that assaying the antioxidant activity of natural antioxidants, it is recommended use of more than one antioxidant assay for a detailed understanding of the antioxidant properties of substances (Č́iž et al. 2010). For this reason, several assays expressing various aspects of the antioxidant action of polyphenols (ORAC, HORAC, DPPH and FRAP) were used. The methods employed, cover different aspects of the antioxidant action and give a broader view of the antioxidant potential of lavender wastes. The ORAC method measures the ability of the antioxidant to scavenge peroxyl radicals via hydrogen atom transfer. These radicals are physiologically the most important ones, and the hydrogen atom transfer is the most physiologically relevant mechanism of antioxidant action. The HORAC method measures the metal-chelating activity of antioxidants under the conditions of Fenton-like reaction; hence it indicates the protecting ability of compounds against hydroxyl radical formation. The DPPH test gives information on the radical scavenging capacity of an antioxidant via transfer of a single electron, whereas the FRAP method is an indicator of the metalreducing capability. The higher concetration of phenolics in SD-L results also in a higher antioxidant activity of the ethanolic extracts - by all the methods used the SD-L antioxidant activity was 25 to $40 \%$ higher than the CO2-L extract. Furthermore, having in mind the experiments for antioxidant activity of the ethanolic extracts, the individual phenolic acids and flavonoids were determined. The results from the analysis are presented in Table 2.

Table 2. Phenolic acids and flavonoids in $70 \%$ ethanolic extracts

\begin{tabular}{|c|c|c|}
\hline \multirow{2}{*}{$\begin{array}{l}\text { Phenolic acids, } \text { mg.g }^{-1} \\
\text { DW waste }\end{array}$} & \multicolumn{2}{|c|}{$70 \%$ ethanol extracts } \\
\hline & SD-L & CO2-L \\
\hline Neochlorogenic acid & $0.558 \pm 0.10 a$ & $0.244 \pm 0.08 b$ \\
\hline Caffeic acid & $0.331 \pm 0.09 a$ & $0.222 \pm 0.04 b$ \\
\hline p-Coumaric acid & $1.007 \pm 0.19 a$ & $0.585 \pm 0.10 b$ \\
\hline Ferulic acid & $0.061 \pm 0.05 a$ & $0.077 \pm 0.04 a$ \\
\hline $\begin{array}{l}\text { 3,4-dihydroxy-benzoic } \\
\text { acid }\end{array}$ & $0.306 \pm 0.09 a$ & $0.132 \pm 0.08 b$ \\
\hline Gallic acid & $0.183 \pm 0.04 a$ & $0.064 \pm 0.07 b$ \\
\hline Rosmarinic acid & $0.177 \pm 0.02 a$ & $0.063 \pm 0.01 b$ \\
\hline TOTAL & $2.62 \pm 0.18 a$ & $1.39 \pm 0.11 b$ \\
\hline \multicolumn{3}{|l|}{$\begin{array}{l}\text { Flavonoids, mg. } \mathrm{g}^{-1} \mathrm{DW} \\
\text { waste }\end{array}$} \\
\hline Quercetin & $0.293 \pm 0.08 a$ & $0.294 \pm 0.04 a$ \\
\hline Quercetin-3- $\beta$-glucoside & $0.778 \pm 0.09 a$ & $1.351 \pm 0.10 b$ \\
\hline Myricetin & $0.217 \pm 0.06 a$ & $0.129 \pm 0.07 a$ \\
\hline Kaempferol & $0.151 \pm 0.04 a$ & $0.066 \pm 0.01 b$ \\
\hline Naringin & $0.402 \pm 0.02 a$ & $0.304 \pm 0.58 b$ \\
\hline Naringenin & $0.034 \pm 0.01 a$ & $0.071 \pm 0.01 b$ \\
\hline Catechin & $1.274 \pm 0.10 a$ & $0.689 \pm 0.10 b$ \\
\hline Epicatechin & $0.567 \pm 0.09 a$ & - \\
\hline TOTAL, mg.100 ${ }^{-1} \mathrm{ml}$ & $3.721 \pm 0.11 a$ & $2.911 \pm 0.12 b$ \\
\hline \multicolumn{3}{|c|}{$\begin{array}{l}\text { Data were expressed as Mean } \pm \text { SD }(n=3) \text {. } \\
a, b \text { - different letters indicated that values of the } \\
\text { means in the rows are significantly different }\left(\mathrm{p}^{*}\right. \\
<0.05) \text {. }\end{array}$} \\
\hline
\end{tabular}

Again the results suggested that in the SD-L residue the biologically active substances were less extracted than in the CO2-L waste - the total amount of phenolic acids in SD-L and $\mathrm{CO} 2-\mathrm{L}$ were $2.62 \pm 0.18$ and $1.39 \pm 0.11 \mathrm{mg}^{-\mathrm{g}^{-1}}$ DW waste, respectively. Similar trend of the results was observed for the amount of flavonoids present in the extracts of both wastes $-3.72 \pm 0.11 \mathrm{mg} . \mathrm{g}^{-1} \mathrm{DW}$ waste for the SD-L and $2.91 \pm 0.12 \mathrm{mg} . \mathrm{g}^{-1}$ DW waste for the CO2-L residue. From the phenolic compounds determined in both extracts the highest concentration had p-coumaric acid $-1.007 \pm 0.19$ and $0.585 \mathrm{mg} \cdot \mathrm{g}^{-1} \mathrm{DW}$ wastes for SD-L and CO2-L, respectively. The catechin (1.274 mg. $\mathrm{g}^{-1}$ DW waste) was the most abundant flavonoid in 
SD-L, while the quercetin-3- $\beta$-glucoside $\left(1.351 \pm 0.10 \mathrm{mg} \cdot \mathrm{g}^{-1} \mathrm{DW}\right)$ was found to be the most abundant in the CO2-L waste.

Determination of volatile and non-volatile polar substances in lavender waste ethanolic extracts. In the subsequent analysis by GC-MS were determined the volatile and non-volatile polar compounds present in the $70 \%$ ethanolic extracts. The results are presented in Tables 3 and 4 . From the group of the non-volatile polar metabolites predominate the organic acids mainly malic acid $(344.20 \pm 11.08$ and $258.14 \pm 14.32 \mu \mathrm{g} . \mathrm{g}^{-1}$ DW extract for SD-L and CO2-L, respectively), linoleic acid ( $151.84 \pm 6.88$ and $113.88 \pm 5.26 \mu \mathrm{g} . \mathrm{g}^{-1}$ DW extract for SD-L and $\mathrm{CO} 2-\mathrm{L}$, respectively), gluconic acid $\left(100.77 \pm 5.32\right.$ and $75.53 \pm 4.62 \mu \mathrm{g} . \mathrm{g}^{-1} \mathrm{DW}$ extract for SD-L and CO2-L, respectively) and stearic acid $\left(170.44 \pm 4.87\right.$ and $151.58 \pm 3.96 \mu \mathrm{g} . \mathrm{g}^{-1} \mathrm{DW}$ extract for SD-L and CO2-L, respectively). Beside these acids, in both waste materials were found in significant amounts $\alpha$-linolenic acid (an essential $\omega-3$ fatty acid), caffeic and protocatehuic acids which had strong antioxidant activities and contribute significantly to the biological value of the extracts. The major aroma constituents found were linalool (30.68 \pm 0.99 and $28.86 \%$ of TIC for SD-L and CO2-L, respectively) and linalyl acetate $(25.82 \pm 0.85$ and $20.97 \pm 1.05 \%$ of TIC for SD-L and $\mathrm{CO} 2-\mathrm{L}$, respectively). Linalool and linalyl acetate contribute significantly to the biological activity of the extracts and hence the wastes and were found to inhibit the growth of Escherichia coli, Staphylococcus aureus, Pseudomonas aeruginosa (Jirovetz et al. 2006). Besides linalool showed potent insecticidal, antitumor, anti-inflammatory and antimicrobial action against Staphylococcus aureus, Escherichia coli, Yersinia enterocolitica, Pseudomonas aeruginosa and Klebsiella pneumoniae, and it was used in medicine, food and plant protection (Jirovetz et al. 2006) Other minor contributors to the antimicrobial, anti-inflammatory and insecticidal activities found in the $70 \%$ ethanolic extracts were $\beta$-caryophyllene, $( \pm)$ lavandulyl acetate, lavandulol, ocimene, terpinene-4-ol, limonene, etc (Dorman and Deans 2000; Jirovetz et al. 2006).
The steam distillation process extracts the majority of the essential oil components but significant part remains in the distilled biomass (Tiliacos et al. 2008; Zheljazkov and Astatkie 2012). Summarizing the results for volatile and non-volatile polar metabolites in both waste extracts it could be concluded that in all the cases the SD-L extracts (residue) contain the determined compounds in higher concentrations than in the CO2-L extracts (residues). This also suggests that the $\mathrm{CO}_{2}$-extraction extracts better all the substances (besides the targeted industrially aroma compounds) from the raw plant material.

\section{Conclusions}

The present study focus on two plant wastes from essential oil industry - one obtained from steam distilled lavender (SD-L) and one from subcritical $\mathrm{CO}_{2}$ extraction of lavender (CO2-L). The lavender wastes showed strong antioxidant capacity with potential beneficial effect on addition in foodstuffs. In all the analysis made (antioxidant activity, total and individual phenolic compounds, content of volatile and non-volatile polar metabolites) the SD-L ethanolic extracts showed the highest results (concentrations) than the CO2-L extract. For the first time lavender residues from $\mathrm{CO}_{2}$-extraction was investigated for its antioxidant activity, polyphenol composition and aroma metabolites, and comparison with SD-L was performed. In general, the results suggested that the lavender waste were promising source of antioxidants and compounds with potent antimicrobial activity, and have the potential for application in the food industry as cheap biopreservative agent.

\section{Acknowledgements}

The authors would like to thank the distillery ECOMAAT Ltd. (Mirkovo, Sofia region, Bulgaria) and personally of Eng. Dorian Krachmarov for its support and the provision of lavender wastes. This research has been financially supported by the Scientific Fund (project № 01/17-H 2017) of the University of Food Technologies - Plovdiv, Bulgaria. 
Table 3. Polar non-volatile substances in ethanolic extracts. RI - relative index (Kovats retention index).

\begin{tabular}{|c|c|c|c|}
\hline \multirow{2}{*}{ Compound } & \multirow{2}{*}{$\mathbf{R I}$} & SD-L & CO2-L \\
\hline & & \multicolumn{2}{|c|}{$\%$ of TIC } \\
\hline Glycerol & 1266 & $258.39 \pm 10.15^{a}$ & $193.79 \pm 8.91^{b}$ \\
\hline Phosphoric acid & 1278 & $17.27 \pm 1.26^{a}$ & $14.45 \pm 0.99^{b}$ \\
\hline Succinic acid & 1310 & $59.01 \pm 2.36^{a}$ & $44.26 \pm 3.11^{b}$ \\
\hline Glyceric acid & 1339 & $43.42 \pm 4.15^{a}$ & $32.57 \pm 2.48^{b}$ \\
\hline Fumaric acid & 1355 & $28.23 \pm 1.69^{a}$ & $21.18 \pm 1.35^{b}$ \\
\hline Serine & 1362 & $22.22 \pm 0.58^{a}$ & $19.17 \pm 0.78^{b}$ \\
\hline L-Threonine & 1390 & $23.24 \pm 1.14^{a}$ & $17.43 \pm 1.36^{b}$ \\
\hline Malic acid & 1488 & $344.20 \pm 11.08^{a}$ & $258.14 \pm 14.32^{b}$ \\
\hline Pyroglutamic acid & 1512 & $87.90 \pm 2.69^{a}$ & $65.92 \pm 3.98^{b}$ \\
\hline Salycilic acid & 1516 & $20.94 \pm 1.17^{a}$ & $15.75 \pm 1.54^{b}$ \\
\hline L-Aspartic acid & 1531 & $19.34 \pm 0.96^{a}$ & $16.71 \pm 0.85^{b}$ \\
\hline L-Threonic acid & 1528 & $45.86 \pm 2.31^{a}$ & $34.40 \pm 2.68^{b}$ \\
\hline Vanillic acid & 1758 & $16.50 \pm 1.41^{a}$ & $12.37 \pm 0.97^{b}$ \\
\hline Protocatechuic acid & 1813 & $19.72 \pm 1.01^{a}$ & $18.29 \pm 1.23^{a}$ \\
\hline Quinic acid & 1843 & $12.96 \pm 0.64^{a}$ & $9.72 \pm 0.95^{b}$ \\
\hline Syringic acid & 1888 & $18.50 \pm 1.12^{a}$ & $17.62 \pm 1.36^{a}$ \\
\hline Glucitol & 1930 & $106.57 \pm 8.51^{a}$ & $79.18 \pm 6.35^{b}$ \\
\hline Gluconic acid & 1991 & $100.77 \pm 5.32^{a}$ & $75.53 \pm 4.62^{b}$ \\
\hline Glucaric acid & 2013 & $98.90 \pm 2.11^{a}$ & $74.17 \pm 3.85^{b}$ \\
\hline Myo-Inositol & 2090 & $25.04 \pm 2.40^{a}$ & $18.78 \pm 2.95^{b}$ \\
\hline Stearic acid & 2132 & $170.44 \pm 4.87^{a}$ & $151.58 \pm 3.96^{b}$ \\
\hline Caffeic acid & 2140 & $32.37 \pm 2.35^{a}$ & $24.28 \pm 2.24^{b}$ \\
\hline Linoleic acid & 2209 & $151.84 \pm 6.88^{a}$ & $113.88 \pm 5.26^{b}$ \\
\hline$\alpha$-Linolenic acid & 2217 & $67.45 \pm 1.98^{a}$ & $50.59 \pm 1.30^{b}$ \\
\hline Stigmasterol & 3315 & $56.86 \pm 1.83^{a}$ & $42.64 \pm 1.75^{b}$ \\
\hline$\beta$-Sitosterol & 3355 & $20.81 \pm 0.97^{a}$ & $15.61 \pm 0.95^{b}$ \\
\hline
\end{tabular}

Data were expressed as Mean $\pm \mathrm{SD}(\mathrm{n}=3)$; $\mathrm{nd}$ - not determined.

$\mathrm{a}, \mathrm{b}$ - different letters indicated that values of the means in the columns are significantly different $\left(\mathrm{p}^{*}<0.05\right)$. 
Table 4. Polar volatile substances in ethanolic extracts. RI - relative index (Kovats retention index); $\%$ of TIC - total ion current.

\begin{tabular}{|c|c|c|c|}
\hline \multirow{2}{*}{ Compound } & \multirow{2}{*}{$\mathbf{R I}$} & SD-L & CO2-L \\
\hline & & \multicolumn{2}{|c|}{$\%$ of TIC } \\
\hline$\alpha$-Pinene & 939 & $0.17 \pm 0.02^{a}$ & $0.13 \pm 0.03^{a}$ \\
\hline Camphene & 954 & $0.14 \pm 0.01^{a}$ & $0.11 \pm 0.01^{a}$ \\
\hline 1-Octen-3-ol & 979 & $0.20 \pm 0.01^{a}$ & $0.15 \pm 0.02^{b}$ \\
\hline 3-Octanone & 984 & $1.91 \pm 0.11^{a}$ & $1.48 \pm 0.09^{b}$ \\
\hline$\beta$-Myrcene & 991 & $0.89 \pm 0.05^{a}$ & $0.69 \pm 0.10^{b}$ \\
\hline$\beta$-Pinene & 979 & $0.65 \pm 0.09^{a}$ & $0.50 \pm 0.06^{a}$ \\
\hline 3-Octanol & 999 & $0.49 \pm 0.04^{a}$ & $0.38 \pm 0.02^{b}$ \\
\hline p-Cymene & 1019 & $0.16 \pm 0.01^{a}$ & $0.13 \pm 0.01^{a}$ \\
\hline Limonene & 1025 & $1.04 \pm 0.11^{a}$ & $0.81 \pm 0.15^{a}$ \\
\hline Eucalyptol & 1031 & $0.73 \pm 0.10^{a}$ & $0.57 \pm 0.08^{a}$ \\
\hline (Z)- $\beta$-Ocimene & 1039 & $2.39 \pm 0.25^{a}$ & $1.86 \pm 0.15^{b}$ \\
\hline (E)- $\beta$-Ocimene & 1049 & $2.51 \pm 0.21^{a}$ & $1.95 \pm 0.22^{b}$ \\
\hline$\gamma$-Terpinene & 1060 & $0.28 \pm 0.02^{a}$ & $0.22 \pm 0.03^{a}$ \\
\hline Linalool & 1097 & $30.68 \pm 0.99^{a}$ & $28.86 \pm 0.16^{b}$ \\
\hline Camphor & 1146 & $0.11 \pm 0.01^{a}$ & $0.09 \pm 0.01^{a}$ \\
\hline Borneol & 1169 & $0.43 \pm 0.04^{a}$ & $0.34 \pm 0.05^{a}$ \\
\hline Lavandulol & 1173 & $1.11 \pm 0.09^{a}$ & $0.87 \pm 0.08^{b}$ \\
\hline Terpinene-4-ol & 1177 & $1.49 \pm 0.12^{a}$ & $1.16 \pm 0.12^{b}$ \\
\hline Cryptone & 1183 & $0.39 \pm 0.02^{a}$ & $0.31 \pm 0.03^{a}$ \\
\hline$\alpha$-Terpineol & 1189 & $3.14 \pm 0.15^{a}$ & $2.44 \pm 0.24^{b}$ \\
\hline Geraniol & 1253 & $0.21 \pm 0.02^{a}$ & $0.16 \pm 0.01^{b}$ \\
\hline Linalyl acetate & 1257 & $25.82 \pm 0.85^{a}$ & $20.97 \pm 1.05^{b}$ \\
\hline $\begin{array}{l}( \pm) \text {-Lavandulyl } \\
\text { acetate }\end{array}$ & 1290 & $3.67 \pm 0.32^{a}$ & $2.85 \pm 0.41^{b}$ \\
\hline Neryl acetate & 1366 & $0.70 \pm 0.02^{a}$ & $0.55 \pm 0.06^{b}$ \\
\hline Geranyl acetate & 1382 & $1.36 \pm 0.04^{a}$ & $1.06 \pm 0.06^{b}$ \\
\hline$\beta$-Bourbonene & 1388 & $0.15 \pm 0.01^{a}$ & $0.12 \pm 0.01^{a}$ \\
\hline$\beta$-Caryophyllene & 1419 & $5.00 \pm 0.49^{a}$ & $3.89 \pm 0.34^{b}$ \\
\hline (E)-b-farnesene & 1458 & $4.98 \pm 0.36^{a}$ & $3.87 \pm 0.25^{b}$ \\
\hline Germacrene D & 1482 & $0.96 \pm 0.05^{a}$ & $0.75 \pm 0.02^{b}$ \\
\hline Caryophyllene oxide & 1580 & $0.23 \pm 0.01^{a}$ & $0.18 \pm 0.02^{a}$ \\
\hline n-Heptadecane & 1700 & nd & $0.67 \pm 0.02$ \\
\hline Farnesyl alcohol & 1725 & nd & $0.97 \pm 0.03$ \\
\hline n-Nonadecane & 1901 & nd & $1.48 \pm 0.08$ \\
\hline 10-Heneicosene & 2093 & nd & $1.53 \pm 0.10$ \\
\hline n-Heneicosane & 2100 & nd & $1.67 \pm 0.21$ \\
\hline n-Docosane & 2200 & nd & $1.03 \pm 0.13$ \\
\hline n-Tricosane & 2300 & nd & $0.86 \pm 0.09$ \\
\hline n-Tetracosane & 2400 & nd & $1.42 \pm 0.14$ \\
\hline n-Pentacosane & 2503 & nd & $1.17 \pm 0.12$ \\
\hline
\end{tabular}

Data were expressed as Mean $\pm \mathrm{SD}(\mathrm{n}=3)$; nd - not determined.

$\mathrm{a}, \mathrm{b}$ - different letters indicated that values of the means in the columns are significantly different $\left(\mathrm{p}^{*}<0.05\right)$. 


\section{References}

Číž M., Čížová H., Denev P., Kratchanova M., Slavov A., Lojek A. Different methods for control and comparison of the antioxidant properties of vegetables. Food Control, 2010, 21(4): 518-523. https://doi.org/10.1016/j.foodcont.2009.07.017

Daramwar P.P., Rincy R., Niloferjahan S., Krithika R., Gulati A., Yadav A., Sharma R., Thulasiram H.V. Transformation of $( \pm)$-lavandulol and $( \pm)$ tetrahydrolavandulol by a fungal strain Rhizopus oryzae. Bioresource Technology, 2012, 115: 70-74. https://doi.org/10.1016/j.biortech.2011.11.038

Dorman H., Deans S. Antimicrobial agents from plants: antibacterial activity of plant volatile oils. Journal of Applied Microbiology, 2000, 88(2): 308-316. https://doi.org/10.1046/j.1365-2672.2000.00969.x

Elguea-Culebras G.O., Sanchez-Vioque R., Santana-Meridas O., Herraiz-Penalver D., Carmona M., Berruga M.I. In vitro antifungal activity of residues from essential oil industry against Penicillium verrucosum, a common contaminant of ripening cheeses. LWT - Food Science and Technology, 2016, 73(11): 226-232. https://doi.org/10.1016/j.lwt.2016.06.008

Jirovetz L., Eller G., Buchbauer G., Schmidt E., Denkova Z., Stoyanova A., Nikolova R., Geissler M. Chemical composition, antimicrobial activities and odor description of some essential oils with characteristic floral-rosy scent and of their principal aroma compounds. In: Recent Research Developments in Agronomy \& Horticulture. Public-law foundation of the Federal state of Lower Saxony, Leibniz, 2006, pp. 1-12, ISBN: 8178951924.

Kratchanova M., Gocheva M., Pavlova E., Yanakieva I., Nedelcheva D., Kussovski V., Slavov A. Characteristics of pectic polysaccharides from leek obtained through consecutive extraction with various reaction agents. Bulgarian Chemical Communication, 2008, 40(4): 561568.

Lesage-Meessen L., Bou M., Sigoillot J.C., Faulds C.B., Lomascolo A. Essential oils and distilled straws of lavender and lavandin: a review of current use and potential application in white biotechnology. Applied Microbiology and Biotechnology, 2015, 99(8): 3375-3385. https://doi.org/10.1007/s00253-015-6511-7

Marumoto S., Miyazawa M. Microbial reduction of coumarin, psoralen, and xanthyletin by Glomerella cingulata. Tetrahedron, 2011, 67(2): 495-500. https://doi.org/10.1016/j.tet.2010.10.089

Méndez-Tovar I., Herrero B., Pérez-Magariño S., Pereira J.A., Asensio-S.-Manzanera M.C. By-product of Lavandula latifolia essential oil distillation as source of antioxidants. Journal of food and drug analysis, 2015, 23(2): 225-233. https://doi.org/10.1016/j.jfda.2014.07.003

Noma Y., Asakawa Y. Biotransformation of monoterpenoids by microorganisms, insects, and mammals. In: Handbook of essential oils: science, technology and applications (Hüsnü Can Baser K, Buchbauer G Eds.). Taylor \& Francis Group, Boca Raton, 2010, pp. 585-736.

Singleton V.L., Rossi J.A.J. Colorimetry of total phenolics with phosphomolybdic-phosphotungstic acid reagents.
American Journal of Enology and Viticulture, 1965, 16(3): 144-158.

Slavov A., Panchev I., Kovacheva D., Vasileva I. Physicochemical characterization of water-soluble pectic extracts from Rosa damascena, Calendula officinalis and Matricaria chamomilla wastes. Food Hydrocolloids, 2016, 61(12): 469-476. https://doi.org/10.1016/j.foodhyd.2016.06.006

Slavov A., Denev P., Panchev I., Shikov V., Nenov N., Yantcheva N., Vasileva I. Combined recovery of polysaccharides and polyphenols from Rosa damascena wastes. Industrial Crops and Products, 2017, 100(6): 8594.

https://doi.org/10.1016/j.indcrop.2017.02.017

Tiliacos C., Gaydou E.M., Bessière J.-M., Agnel R. Distilled lavandin (Lavandula intermedia Emeric ex Loisel) wastes: a rich source of coumarin and herniarin. Journal of Essential Oil Research, 2008, 20(9): 412-413.

Zheljazkov V.D., Astatkie T. Distillation waste water can modify peppermint (Mentha $\times$ piperita $\mathrm{L}$.) oil composition. Industrial Crops and Products, 2012, 36(1): 420-426. https://doi.org/10.1016/j.indcrop.2011.10.007 